\title{
Surfacing the Assumptions: Pursuing Critical Literacy and Social Justice in Preservice Teacher Education
}

\author{
Lorayne Robertson \\ University of Ontario Institute of Technology \\ Janette Hughes \\ University of Ontario Institute of Technology
}

\begin{abstract}
This paper outlines a four-year study of a preservice education course based on a socioconstructivist research framework. The preservice English Language Arts course focuses on critical literacy and teaching for social justice while employing digital technologies.The research study examines two concepts across all aspects of the course: 1) new literacies and multiliteracies; and 2) technology-supported transformative pedagogy for social and educational change. While the authors originally undertook the study to evaluate separate assignments of the course, the lens of the two themes has provided an opportunity for a scholarly review of their teaching practices. Research data include three course assignments over a 2-year period; an open-ended survey; and focus group and individual interviews with pre-service teachers. The authors discuss some of the affordances, challenges, and learnings associated with preparing teachers to teach critical literacy in a digital age. They also consider the development of critical literacy skills which encourage preservice teachers to bring their literacy histories and assumptions to the surface, examine them critically, and consider social justice alternatives.
\end{abstract}

Key Words: critical literacy, social justice, new literacies, multiliteracies, preservice teacher education, transformative learning

Lorayne Robertson, Assistant Professor, and Janette Hughes, Associate Professor, teach the Language Arts and English preservice courses in the Faculty of Education at the University Institute of Technology. Their research interests include multiple literacies, critical media literacy, and technology-supported learning and teaching.

Email: lorayne.robertson@uoit.ca

Email: janette.hughes@uoit.ca 


\section{Introduction}

We designed this reflective study to examine the teaching and learning outcomes of a preservice teacher education course at a laptop university. The findings reported here summarize four years of research on a single English Language Arts (ELA) course taught by two preservice teacher educators to four annual cohorts of elementary preservice teachers; each cohort was enrolled for ten months in a post-Baccalaureate teacher education program. The purposes of this systematic review of our teaching practice are two-fold: (1) to identify and discuss some of the challenges associated with preparing preservice teachers to teach critical literacy in an era where their future students will engage in many digital literacy activities both inside and outside of class; and (2) to identify the transformative learning (Cranton \& King, 2003; Keegan, 2011; King, 2002) opportunities for preservice teachers that are enabled through engagement with new literacies (Lankshear \& Knobel, 2006) and technologies (Kellner, 2000), and through presenting opportunities to teach for social justice (Brandes \& Kelly, 2004).

\section{Context: From Literacy to Literacies}

The authors teach two consecutive semesters of a blended but mostly face-to-face ELA course in a preservice teacher education program that has an overall technology focus. From the first class, the preservice teachers are asked to engage in critical literacy. For example, the course begins with an instant, early, and deliberate immersion into the complexities of multiple literacies (Bearne, 2003; Cope \& Kalantzis, 2000; Kress, 2003) including media literacy, computer literacy, and digital literacy. Secondly, the preservice teachers are asked to consider the concept of new literacies (Kellner, 2000; Lankshear \& Knobel, 2006) as a set of social practices which may or may not include digital technologies. Third, the preservice teachers are asked to consider how literacies are constructed socially; how these literacies are reflected in schooling and in life histories (Jewitt, 2008a; New London Group, 1996); and how critical literacy practices (Lewison, Flint \& Van Sluys, 2002; McLaughlin \& DeVoogd, 2004) might lead teachers toward social justice purposes, and empower groups who traditionally have been excluded from the curriculum (Brandes \& Kelly, 2004).

To encourage an understanding of education as a force for democracy (Kellner, 2000; New London Group, 1996) all elements of the course: the classroom activities; the asynchronous discussions; the lessons preservice teachers are asked to create; and their assignments, are modeled on a multiliteracies pedagogical framework that encourages teachers to examine their own schooling histories and reflect on how they have impacted their views on literacy. This framework also asks them to interrogate voice and representation in resources and encourages teachers to be change agents for social justice (New London Group, 1996). The course readings provide examples of how social justice issues can be integrated into classroom practices with children and adolescents (e.g., Moller, 2002) and the readings also challenge them to bring assumptions to the surface and to consider the impact of power, voice, and representation in curriculum materials.

To illustrate this early immersion into understanding critical literacy, in their first class, the preservice teachers examine inclusive curriculum resources and compare them to the curriculum materials they experienced in their own schooling. For example, the first read aloud book is All the Colors of the Earth (Hamanaka, 1994) within which each child's characteristics are valued equally in beautifully descriptive, poetic language. Inevitably, the preservice teachers 
begin to discuss how their literary experiences have impacted on their own feelings of exclusion or belonging in school. Those preservice teachers who were left out of the curriculum discuss it with their peers. Some preservice teachers who have never questioned the curriculum realize that their families and their lives were more included and legitimized in school. This raises issues of hegemonic representations starting with the first class discussion. This is followed by a reflective reading on privilege (McIntosh, 1989) and online discussions in small groups.

The assignments of the course also encourage an instant immersion into multiliteracies and conceptual complexity. The preservice teachers prepare and present their literacy life histories in the form of five-minute digital stories using text, sound, graphics, focus and movement built into a simple software package such as Photo Story 3. They consider both their successes and struggles with literacy acquisition and how their literacy was shaped by social practices. The preservice teachers are invited, but not required, to share their literacy/life digital stories with their peers and many do. In the classroom debrief, they reflect on the diversity of their peers' lived experiences and are asked to consider how this new knowledge would impact their roles as teachers (New London Group, 1996).

For the second assignment, the preservice teachers create social justice digital book talks. Many areas where teachers and students can make a difference are raised through these digital book talks such as: racism, heteronormative family representations, bullying, homelessness, poverty, and many others. The preservice teachers are asked to engage with the picture books by applying four dimensions of critical literacy: disruption of the commonplace; consideration of multiple viewpoints; a focus on the political and social issues; and possible action steps for social justice (Lewison et al., 2002). In doing so, the preservice teachers negotiate meanings. For example, one of the social justice books discussed was, My Princess Boy (Kilodavis, 2010), which is a non-fiction account about the public's lack of acceptance for a boy who likes dresses. After reading the book, the preservice teachers can identify that schools need to be more inclusive, but they have difficulty identifying that certain views seen as natural (such as the devaluing of feminine characteristics) need to be surfaced and interrogated because critical literacy is a practice of negotiating meaning (Ferrarelli, 2007).

The course is designed so that the preservice teachers utilize their critical literacy skills, technology skills and considerations of social justice actions (Conklin, 2008) concurrently throughout their subsequent assignments. They also use an open source e-book authored by Hughes for their course readings (http://faculty.uoit.ca/hughes/). We undertook a study of the learning outcomes from the course in order to provide evidence for our own review and reflection. At the present time, the study is in its fourth year of data collection and analysis. This study has both reflective and retrospective elements, as the data and reflections inform and deepen our practice. While the study actually commenced as four distinct research components, it has evolved to the point that broader themes have surfaced. The first study was qualitative research based on three data sets: the preservice teachers' digital stories, their written reflections, and interviews (Robertson, Hughes \& Smith, 2012). Next, we used a case study approach to examine preservice teachers' uses of digital video (Hughes \& Robertson, 2010). Third, we analyzed the social justice book talks and lessons created by the preservice teachers and discussed them with the preservice teachers in interviews (Hughes \& Robertson, 2011). The fourth study was an analysis of the level of criticality evident in critical media literacy lesson plans and an open-ended survey (Robertson \& Hughes, 2011). There is still one course assignment that has not been researched: the integrated units. 
It is not these individual research components which inform the study at the present time, however, but rather a consideration of how the integrated, thematic elements have emerged as important through this reflective examination of our practice: new literacies (Jewitt, 2008a; Lankshear \& Knobel, 2006); new literacies, new technologies and democratic teaching (Kellner, 2000); and multiliteracies and teaching for social justice (Keegan, 2011; New London Group, 1996). In this paper, we examine the findings of all of the previous research in our course, consider what understandings have surfaced this research, and re-examine our current practice through two lenses: multiliteracies (New London Group, 1996) and teaching for social justice (Brandes \& Kelly, 2004).

\section{Theoretical Framework}

When considering how to teach with new literacies (Jewitt, 2008a; Kellner, 2000; Lankshear \& Knobel, 2006) and multiliteracies (New London Group, 1996), there are two key considerations to bring to the attention of preservice teachers. First, there is the transition from thinking about literacy as a single skill that an individual possesses at a particular level, to considering the term as a plural noun: a set of complementary practices that are applied in different ways, based on the setting and circumstance. The literacies used to communicate in an email differ from the literacy skills used to enjoy a novel, for example. Secondly, there is a consideration of how these new literacies can open spaces for teaching and learning to become more accessible, inclusive, and empowering. With new technologies and new ways of collaborating and co-construction of knowledge, there are new possibilities for student ownership of learning. The affordances of technology provide a window for new forms of pedagogy that are more empowering and democratic in their orientation. Theoretical framework that follows is organized around these two constructs: a) the expanding definitions of the term literacy; and b) how to teach and learn with these new, multiple literacies.

\section{New Literacies and Multiliteracies}

In the ELA program reviewed here, there is first of all, a deliberate expansion of the term literacy. While literacy in earlier times referred to the level of acquisition of certain skills by an individual, new thinking of literacies as a plural term brings into consideration different literacy practices, such as those that are situated historically, socially and culturally (Jewitt, 2008a). Many exciting and different literacies are emerging: 1) the school's idea of literacy may not align with the community's; 2) the world of classroom literacy is gradually blending with global literacies; and 3) more aspects of the learners' lives, cultures, knowledge, and experiences are blending into classrooms (Jewitt, 2008a). This blending of the out-of-school experiences of students with their literacy learning offers an opportunity for educators to build on these new literacies. For example, one of the preservice teachers in our course contributed a unit on Dub Poetry for her peers. This gave the preservice teachers an opportunity to expand their (traditional) understandings of poetry, and to broaden and become more inclusive in their considerations of curriculum. It allowed the preservice teacher presenting the Dub poetry to bring her community into the preservice classroom.

Another form of new literacies includes multiple literacies (Bearne, 2003; Cope \& Kalantzis, 2000; Kress, 2003) encompassing computer literacy, digital literacy, critical literacy and media literacy. Jewitt (2008a) conceptualizes these in the form of "modal affordances" 
which have the potential for both expressing meaning and representing meaning which "enable image, sound, and movement to enter the classroom in new and significant ways" (p. 257). Examples of these new literacies include the increasing use of images alongside of text and the use of hypertext. Jewitt concludes that educators need to take advantage of these new literacies, encouraging schools to include students' out-of-school literacies into the classroom. She reminds teachers that the new modal affordances also provide an opportunity to help students develop their understanding of strategies for engaging more effectively and critically with media.

Lankshear and Knobel (2006) offer the same conceptualization of new literacies but make an important distinction between what they call the "technical stuff" of new literacies and the "ethos stuff" (p. 25). The technical aspects include multimodal processes such as the mixing of text, images, and sound. The new aspects of ethos include more participatory and collaborative forms of communication. They offer the consideration that some of the new literacies are not necessarily associated with digital technology advances. We can utilize new forms of collaboration and consultation using print formats, for example.

Kellner (2000) offers another key consideration to this discussion of new literacies and new technologies, calling on educators to reconstruct and to democratize education. He defines multiple literacies as those skills needed to access information, interpret it, engage critically with it, and communicate with it. He supports the use of technology for these purposes, arguing that the use of technology helps learners to understand the world, but it will also help learners and teachers to transform it. In his view, new technologies require teachers to have "new curricula, pedagogy, literacies, practices and goals" (p.246). In particular, he suggests that teachers expand their concept of literacy to include multiple literacies for democratic purposes. Kellner (2000) summarizes in this way:

Individuals should be given the capacities to understand, critique, and transform the social and cultural conditions in which they live, gaining capacities to be creative and transformative subjects and not just objects of domination and manipulation.... Crucially, multiliteracies and new pedagogies must become reflective and critical, aware of the educational, social, and political assumptions involved in the restructuring of education and society that we are now undergoing. (pp. 257-258)

While the ELA course syllabus originally included the study of literacies and the affordances of multiple literacies such as digital literacy, media literacy, and computer literacy, our understanding of the term new literacies (Jewitt, 2008a; Kellner, 2000; Lankshear \& Knobel, 2006) has grown as a result of this research project. Now, when we use that term, we encompass understandings of multiple, different literacies converging into the classroom space, and have a vision of the term literacies that is more expansive, emancipatory, critical, empowering, and oriented toward agency and social justice (Brandes \& Kelly, 2004; Ferrarelli, 2007).

\section{New Pedagogies}


A second theoretical orientation for the ELA program is the adoption of a pedagogy of multiliteracies (New London Group, 1996). There are four pedagogical components within this framework: situated practice, which is the immersion of a learner in practices that are meaningful to his or her professional life within a learning community; overt instruction, which includes lessons and modeling to guide the learning; critical framing, which is intended to help the preservice teachers recognize that literacies are socially constructed within a framework that includes culture and politics; and transformed practice, which we interpret to mean that the preservice teachers are given support to change notions of how they will teach relative to how they were taught (New London Group, 1996).

Applying this theoretical framework to the ELA program, situated practice means that we immerse the preservice teachers in authentic activities that promote educational and social change. In their first assignment, the story of their personal literacy histories, we encourage them to discover how their histories have created their perceptions about literacy. Overt instruction in the context of the course involves direct instruction in deconstructing media and text to surface the assumptions present (Ferrarelli, 2007) while considering the histories and perspectives of their peers through the shared literacy stories; and examining and naming taken-for-granted assumptions, privileges and areas of disadvantage (McIntosh, 1989) that they and their peers have experienced. The action of critical framing means that we encourage our teacher learners to study literacies within a broader context of history, politics, culture, and ideologies - asking them to consider whose voices have been traditionally dominant and whose are marginalized or silenced. In a new era of digital literacy, this includes discussions about how to include students' out-of-school literacies in the classroom (Jewitt, 2008a). We interpret transformed practice to mean that preservice teachers want to change their practices from the way that they were taught because they see a need for educational and social change. We want preservice teachers to be comfortable discussing social justice issues and projects in their future classrooms, even though this may not have been an aspect of their own schooling.

In his seminal work on the importance of considering teacher beliefs in educational research, Pajares (1992) suggests that teachers' beliefs should play a role in educational research as long as careful consideration is given to key assumptions that underlie those beliefs. In the first assignment in the course - the creation of a digital literacy story -- preservice teachers recall incidences from their own classroom experiences with literacy and consider how these experiences helped shape or influence them. When they view the literacy stories of their peers, they are confronted with their own assumptions. For example, preservice teachers will share experiences with ethnocentrism and assimilation which challenge the previous assumptions of their peers who saw that same curriculum as natural and did not question it. Teachers have a responsibility to understand how schools can perpetuate dominance. Preservice teachers who, for example, believe that issues of race do not persist need to listen to the preservice teachers who face racial assumptions daily. Through exposure to others' different experiences of literacy, the preservice teachers reflect on these underlying assumptions and what they mean for their future classrooms.

In a similar process, King (2002) explores how teachers in graduate school examine and change their teaching practices and perspectives with technology. Central to her argument is the concept of the teacher as a critical reflective practitioner (e.g. Brookfield, 1995; Cranton \& King, 2003). Cranton and King (2003) see professional dialogue and collaboration as key elements in supporting teachers in changes in practice or transformative learning. They observe that the goal 
of those who teach teachers is to open their perspectives to new ways of thinking about teaching. Similarly, Keegan (2011) finds that successful teaching and learning with technology is transformative in nature and includes critical reflection, discussion and action. He describes it as, "the process by which we call into question our taken-for granted habits of mind or mindsets to make them more inclusive, discriminating, open and reflective in order to guide our actions" (p. 66). This view of transformative learning for adults (Cranton \& King, 2003; Keegan, 2011; Mezirow, 2000) aligns with the pedagogy of multiliteracies (New London Group, 1996).

Theories such as a multiliteracies pedagogy (New London Group) help to define transformative learning for teachers including preservice teachers. As a result, part of the research study design became the search for evidence that our preservice teachers saw a need for educational and social change, and were changing their beliefs. In the research, we looked for evidence that they could recognize and name normalizing structures of race, class, gender, sexuality, and appearance; and that they acknowledged a need for more democratic, social justice approaches.

\section{Methodology}

The investigation of the preservice teachers' understandings from the ELA course did not begin as a study of the entire course, but started as an examination of the individual assignments from the course combined with focus groups and interviews to understand at a deeper level both what and how the preservice teachers were learning. Because of this approach, the research methods differ for each assignment. The methodology section first explains the different research components and methods used. The second section of the methodology explains how each of these separate components was analyzed.

\section{Research Components}

In this section, we give an overview of each of the components of the research, identify the data sources, and discuss how the data were analyzed. The bulk of the research followed a qualitative design; however, we also did some open-ended surveying which allowed for triangulation with the other data, which included observations, field notes, individual interviews, focus groups and visual and content analyses of the print and digital texts created by the preservice teachers.

The first research component was based on the preservice teachers' personal narratives/life histories in the form of digital literacy stories. For this analysis, we collected 150 digital stories and 150 written reflections from preservice teachers over a three-year period. This was combined with focus group discussions and 6 face-to-face open-ended interviews with the preservice teachers who used digital stories in their practice teaching sessions. Separately, we each examined the digital stories, reflections and interviews for evidence of changes to the preservice teachers' previously-held paradigms or assumptions about literacy, teaching, and teaching using digital technologies.

The second research component focused on the use of digital media. Through the analysis of in-depth case studies based on three of our preservice teachers, we identified four persistent themes related to their use of digital media both in our program and in their teaching practice, either during field placements or as beginning teachers. Following Stake's (2000) practices for 
in-depth case studies, the data for this study drew on the preservice teachers' written reflections, transcribed interviews, and the digital and multimodal texts created by them and their students. Our findings suggest that there are important implications for education if we focus on the performative, collaborative and multimodal affordances of digital media, as well as tap into the potential for using digital media as "identity texts" (Cummins, Brown \& Sayers, 2007).

The third research component in our study employed multiple data sources including: a) ninety digital book talks created by the preservice teachers; b) reflections on the book talks; and c) interviews. We examined their use of digital book talks to support classroom discussions about social justice issues. The book talks were analyzed and were rated based on criteria such as the quality of their hook to engage students to read the book; the quality of the questions raised related to social justice, and the teaching activities that were proposed by the preservice teachers. From the original group of ninety book talks, we selected eight of the more interesting and effective ones to analyze more closely. We conducted interviews with the creators of these book talks.

The fourth component was based on the creation of critical media literacy lesson plans and the data included: a) 48 surveys of preservice teachers' understandings of social justice; b) document analysis of 71 digital lessons produced by them over a two-year period; and c) twelve open-ended interviews on the design of the critical media literacy lessons. We conducted a content analysis (Berg, 2004) of the open-ended survey responses to identify themes informing their pre and post impressions about the importance of incorporating social justice issues into their Language classes. For the analysis of the critical media literacy lessons, using blind review, we assessed the critical media literacy lessons as having one of four orientations: Protectionist, Media Art, Media Literacy or Critical Media Literacy, employing a framework adapted from the work of Kellner and Share (2007). We subsequently met to compare and discuss the ratings assigned to the lessons.

\section{Data Analysis}

There were multiple approaches to the data analysis in this study. Analysis of the data from the preservice teachers' reflections on the digital stories and their interviews required several different layers of coding and interpretation of the themes which emerged. We followed traditional coding procedures (Berg, 2004) working individually and then compared findings in order to identify recurring and overlapping thematic and structural patterns (Black, 2007). At a later point in time, we returned to the reflections and tabulated the frequency of some of the key findings based on this categorization of the anecdotal comments.

The multimodal texts (digital stories and book talks) created by the participants were analyzed within a framework of semiotic meta-functions (Kress \& Van Leeuwen, 2001; Jewitt, 2008b; Burn, 2008), which considers design and production as representational, interactive and textual. Because of the complex blending of multimodal data elements, we also used the digital visual literacy analysis method of developing a "pictorial and textual representation of those elements" (Hull \& Katz, 2006, p.41); that is, juxtaposing columns of the written text, the images from digital texts, data from interviews, and field notes to facilitate the "qualitative analysis of patterns" (p.41). Our analysis focused on the various modes of expression (i.e. visual image, gesture, movement) and how these work in concert to create meaning, as well as a focus on the topic of the multimodal text. We were particularly interested in moments that might be interpreted as "turning points" (Bruner, 1994) in the representation of identity and/or the 
conceptual understanding of relevant issues. Where applicable, a cross case analysis was conducted to compare/contrast the cases of the individual participants.

The analysis of the critical media literacy lessons was done in two stages. First, using blind review, the lessons were evaluated according to levels of criticality (Kellner \& Share, 2007). Next, the lessons were analyzed to determine the elements that were missing that could have been included to build criticality.

In the next section, the findings from each of these four research components are reviewed and analyzed using a broader framework of two theoretical constructs: new literacies and multiliteracies; and transformed practice leading to social and educational change.

\section{Findings}

The data analysis of the preservice teacher reflections provided insights into both their overall impressions of the digital story assignment and individual insights. The findings reported here show that four themes were raised by a significant number of preservice teachers. All of the reflections indicated that they found the assignment valuable and learned from it. More than two-thirds of the participants gained important insights about the teachers that they wanted to be. One in three preservice teachers also indicated how their views of literacy were changing. These findings are detailed next, accompanied by the words of the participants.

\section{Findings from the digital stories, written reflections and interviews}

We were initially surprised to find that every preservice teacher who participated in the study indicated that the digital literacy assignment was a positive experience. They indicated that they experienced multiple emotions and found that the assignment touched them in powerful ways. Although they did not use the word transformative, their comments detailed below indicated that the assignment was perspective-changing.

There were, in addition, four findings which were reflected most frequently in the data. First of all, while preservice teachers indicated different areas of struggle in preparing the assignment, the first finding was: Every preservice teacher indicated in the reflection that he or she had gained learning, insights or understanding from the preparation of the digital story. One preservice teacher wrote:

I now realize that teaching literacy is not simply about reading and writing - but rather it requires a far deeper and much more meaningful approach which allows students to think critically, read between the lines, and express themselves in a multitude of forms.

Another wrote:

Creating a digital story was a challenge for me at first. I had never encountered this type of assignment and found myself unable to get started. However, when I eliminated my writer's block, the way I saw literacy shifted. I realized that literacy is multimodal. I saw literacy as much more than the standard definition of being able to read and write. In particular I began to realize that digital and social literacy are especially important for our society and myself personally. 
The second key finding which emerged the most frequently in the data was not an anticipated one; Preservice teachers gained strong and deep understandings from viewing the digital stories of their peers. More than two-thirds of each cohort reported that they had realized gains in understanding from viewing their peers' stories. They wrote that they had "seen each other's histories" and "where the other preservice teachers had been" prior to attending the faculty of education. Based on these digital stories, the preservice teachers articulated that they learned about "not making assumptions", and "not being judgmental" about their peers. They recognized the power of literacy to broaden perspectives and to build empathy. One preservice teacher wrote that she would no longer believe that her reality was another's. Another wrote that he realized now that he had been judgmental and "had made assumptions about others" based on superficial characteristics.

Preservice teachers reported other connections to the viewing of each other's stories, such as a need for differentiated curriculum based on the understanding that each person was different. They reported a better understanding of the needs of English Language learners and that they believed that the viewing of others' digital stories built empathy within the preservice teacher cohort. In addition, preservice teachers reported a developing connection to the learner and empathy for the experiences of their future students in their future classes based on hearing others' literacy histories.

The third finding of this study was that the preservice teachers were able to make connections from the assignment to the kind of teacher they would be in the future. While some of the reflections were deeply personal and rooted in the past, the majority of the preservice teachers (at least two-thirds of the preservice teachers in each cohort) were able to connect their literacy story and that of their peers' to build understandings about changes they would like to make as future teachers. Some of the understandings were clinical and practical, such as deciding to give students the "right to pass" or not requiring them to read aloud. Other understandings were deeper, with students expressing that they realized that their lives had been privileged compared to their peers and that they needed to make sure that every student felt valued and welcomed in their future classes.

A fourth finding was that the preservice teachers found that their views of literacy expanded beyond reading and writing and that multimodal formats provided more spaces for expression. This was articulated by at least one in three preservice teachers in each cohort. For example, one preservice teacher wrote, "Literacy is a unique fabric, a powerful thread, unraveling and weaving throughout a person's life, creating new experiences and opportunities as we go, defining and redefining who we are." While the preservice teachers found the technology requirements and the complexity of the digital story task to be intimidating, they were amazed at how quickly they were able to use the technology to represent themselves more authentically than through written text, or text and pictures alone. In an interview, one preservice teacher reflected:

Creating a digital literacy story proved to be a very valuable learning experience for me. Not only did [it] provide me with an opportunity to learn about the multiple layers of literacy, it gave me a way to enhance my teaching practice. Assigning a digital story was something new and exciting for my students and my associate teacher. 
Similarly, another wrote that the digital story "helped all of us gain a sense of identity, relearning exactly who we are." No preservice teachers told us that the digital medium was restrictive. One participant commented that she valued the digital literacy assignment because it gave her the tools, the space, and the audience to help her to reflect on both her life and her conception of literacy. In her written reflection on the assignment, she commented:

Literacy involves both the ability to make meaning of the world we live in and to communicate meaningfully within these contexts. It is more than words on a page. Through my personal digital story, I was able to present the bullet points of my life with volumes of emotion and memory and presence that mere words could never have done in the same time and space.

One preservice teacher wrote that the point of the digital story was so that "each person could work to find their voice." Surprisingly, three of preservice teachers indicated that the digital format gave them a mask under which they felt more liberated to expose more of themselves. Some individual reflections were quite compelling in their candor. One preservice teacher used the opportunity the digital story created to reveal deeply personal circumstances to the class. Another reported that creating the story allowed her to rebuild her past, opening a door of silence that had been closed for years.

Finally, the findings indicate that starting the Language Arts course with the digital literacy history assignment provides a bridge between the preservice teachers' out-of-school digital literacy practices and the multimodal literacies in the program; it also allows preservice teachers to showcase their digital skills. Some, but not many (less than 20\%) of the preservice teachers are comfortable creating and posting videos prior to enrolling in the BEd program. For the rest, the digital story assignment is initially intimidating but ultimately satisfying.

In summary then, the digital stories are a source of learning and reflection for the preservice teachers. The assignment provides them with insights into each other's literacy learning histories which the preservice teachers utilize to begin to articulate their views of the teacher they want to become. In the next section, findings from the second assignment, the digital book talks indicate that the preservice teachers build on the multimodal aspects of the first assignment while considering their roles as teachers for social justice.

\section{Findings from the digital social justice book talks}

The second course assignment is the creation of a digital book talk based on a social justice issue because book talks can help novice teachers see possibilities for discussion and positive social action. Although the preservice teachers were able to select the social justice books for book talks and create digital book talks, they were challenged by the portion of the assignment that required them to state how they would use the social justice book with their future classes. Approximately one in three preservice teachers was able to create both an effective digital book talk and the critical questions that would accompany it.

When we did a comparative analysis of four of the most effective book talks, we noted that some key features set the more successful book talks apart from the others. For example, three out of four of the best book talks utilized solely illustrations from the book. Perhaps this strategy helped to build the atmosphere and recreate the world of the book. In comparison, all of the less successful book talks utilized images, primarily from the Internet, in addition to the 
book's illustrations. Also, none of the four best book talks provided additional information about the book and author over and above the title and the names of the author and illustrator. The book talks that were the most effective created mood and an artistic world from the start; captured students' interests; and placed students within a context where they could engage with social justice questions and become motivated toward action.

One challenging aspect of the assignment is the requirement to develop critical questions for the class discussion of the book or with designing the lesson activities to accompany the book. In the analysis of their book talks and lesson activities, it became evident that while preservice teachers seemed comfortable with interspersing imaginative/predictive and selfevaluative questions throughout the book talks, they did not include critical questions that demonstrated an understanding of existing inequalities and the need for social change. Half of the teacher candidates struggled with these critical questions. As a result, our fifth finding is that: Preservice teachers require support and critical framing (New London Group, 1996) to articulate the deeper and broader issues of social justice.

In the preservice teachers' lessons to accompany the book talks, less than $10 \%$ of the preservice teachers addressed the positional and representational aspects of text or the understanding that texts are not value-neutral. They also struggled with text deconstruction and reconstruction. This finding is a reminder that critical literacy is a somewhat recent pedagogy. The assignment did immerse them in digital media and encouraged them to see how digital book talks could help them create spaces for their future students to discuss issues of social justice. In terms of our own practice, we noted that new teachers need time and modeling in order to see critical literacy as something that accomplished readers do. Based on the findings from this portion of the research, we have recently placed more of a focus on encouraging teacher candidates to write about their own lives using Christensen's (2004) model of bringing students' lives into the classroom. We hope this modeling will prompt them to bring more of their future students' lives into their classrooms, making the curriculum more inclusive in a natural way. In this way, we hope to raise their awareness that texts and media are not neutral.

The challenges with articulating the social justice issue persisted in the findings for the next assignment in the course, the design of critical media literacy lessons.

\section{Findings from the critical media literacy lessons}

In the next component of the study, we analyzed 71 critical media literacy lessons, the preservice teachers' open-ended surveys of understandings of social justice, and transcripts of teacher interviews following their final practice teaching sessions. In the interviews, the preservice teachers reported that a very small number of their host classrooms had social justice books and social justice approaches, but when preservice teachers did have a chance to see this pedagogy modeled, they had found it to be powerful. Some preservice teachers said that they wanted to be change agents and help children see the sell in media, but others thought that teachers should be a neutral presence that does not influence children. While the number of preservice teachers interviewed was small, the data indicated once again that preservice teachers support social justice teaching but may have difficulty articulating the issues. This was also apparent in the surveys they completed, which are discussed next.

The preservice teachers were asked to complete a voluntary, anonymous, open-ended survey at the beginning of the course and again toward the end of the course. The survey asked them to outline their understandings of critical literacy and the teacher's role in teaching for 
social justice. The majority of those who volunteered for the survey (58 out of a possible 90 preservice teachers) did complete the survey, providing 43 completed pre and post surveys. These surveys were analyzed according to whether or not the preservice teachers provided evidence that their views of critical literacy and teaching for social justice had changed.

The analysis indicated that $12 \%$ of the preservice teachers did not articulate a change in their views. Approximately one in four (23\%) said that their views had changed, but their description of the change was reported in non-specific terminology so that the change in concept or understanding could not be clearly discerned. The majority $(65 \%)$ who completed the survey, however, provided clear evidence that their views of critical literacy and teaching for social justice had changed over the duration of their preservice year. These preservice teachers offered specific examples. They said that teachers had a role to be guides and facilitators to help students read and deconstruct texts and media. The most frequently-reported roles for teachers were as follows: to lead discussions with students; to help students see that all texts are biased; to help students understand that there are multiple perspectives; and to build empathy among students. Other responses included that they saw the role of the teacher was to help students "deconstruct stereotypes" and "challenge oppression, discrimination and stereotypes." Overall, the survey responses led us to our sixth and final finding: Preservice teachers are supportive of the development of critical literacy skills and teaching for social justice.

The preservice teachers offered their critical media lessons for review for the research and these were analyzed based on a framework of criticality developed by Kellner and Share (2007). The analysis revealed that most of the lessons the preservice teachers developed did address media literacy outcomes (85\%). Less than half of the lessons produced by them, however, were assessed as critical according to the critical media analysis framework (Kellner \& Share, 2007) that was applied (see Figure 1).

Figure 1. Distribution of Media literacy lessons per category

\begin{tabular}{|c|c|c|c|c|}
\hline $\begin{array}{l}\text { Media Literacy Approach } \\
\text { (Kellner \& Share, 2007) }\end{array}$ & \# & $\%$ & $\begin{array}{l}\text { Media Literacy } \\
\text { lessons }\end{array}$ & $\begin{array}{l}\text { Critical Media } \\
\text { Literacy } \\
\text { lessons }\end{array}$ \\
\hline Protectionist & 1 & $1 \%$ & & \\
\hline Media as an Art Form & 0 & - & & \\
\hline Media Literacy & 28 & $39 \%$ & & \\
\hline Critical Media Literacy & 15 & $21 \%$ & $\begin{array}{l}85 \% \text { of the } \\
\text { lessons } \\
\text { demonstrated } \\
\text { understanding of } \\
\text { media literacy } \\
\text { concepts }\end{array}$ & $\begin{array}{l}45 \% \text { of the } \\
\text { lessons } \\
\text { demonstrated } \\
\text { understanding } \\
\text { of critical media } \\
\text { literacy } \\
\text { concepts }\end{array}$ \\
\hline Not Applicable & 10 & $14 \%$ & & \\
\hline
\end{tabular}

Note: $n=71$

The finding that less than half of the critical media lessons were, in fact, critical, was important in our study, causing us to reflect deeply on the results, and concomitantly, how an examination of our alignment with the pedagogy of multiliteracies framework (New London Group, 1996) 
might further inform our practice and increase the criticality in this assignment in future years. This was not a new finding, however, because we had found this also in the social justice book talks (Finding 5: Preservice teachers require support and critical framing (New London Group, 1996) to articulate the deeper and broader issues of social justice.)

In summary, we have accumulated and examined a considerable amount of evidence over a four-year period. At each stage of the study, we saw more data that might be gathered to triangulate results and potentially provide deeper insights. While in the past we saw the different components of our study as somewhat distinct, we now interrogate the course using two theoretical orientations as lenses: multiliteracies; and transformed pedagogy for social justice approaches - both of which have foundations in critical literacy. It has been instructive to examine our practice through these broader lenses. We find that, while preservice teachers can and do use digital media to teach in interesting, engaging, and innovative ways, they appear to be much more comfortable with the new technologies than with the articulation of deeper understandings about critical literacy, critical media literacy, and teaching for social justice.

\section{Discussion}

More than a decade has passed since Alvermann and Hagood announced that, "Literacy is on the verge of reinventing itself" (2000, p. 193). As they considered the world of the $21^{\text {st }}$ century learner, they saw that the rapid advances of technology would have significant implications for literacy educators. They commented that binaries are at play in school systems, one of which is the distinction between the "official knowledge accepted by the dominant culture" (p. 200) and the students' out-of-school lives which include popular culture. They theorize that, "Binaries forged and instantiated within the discourse of school leave little room for literacy instruction of the multiliteracies of students' everyday lives" (2000, p. 201). They and others see the study of critical media literacy as a "natural" element of literacy instruction (p. 201) that provides an opportunity to blur the distinctions between the traditional, established curriculum and life.

Alvermann and Hagood (2000) were interested also in the pedagogical implications of helping students enjoy media (pleasure) while simultaneously acquiring the skills (work) to identify how media could potentially silence them through its representations. They identified critical media studies questions to be, "Who does this text address through its words, images and sounds? Who is absent in this text, and what might explain that absence? Whose interests are served in this text? How am I positioned by it?" They argue that a crucial theoretical construct to be acknowledged is "mode of address" or how the reader/viewer is positioned by the communication (p. 201). They employ a multiliteracies pedagogical framework (New London Group, 1996) to explain how a teacher might include mode of address to help students deconstruct and reconstruct media text. We find that these examples such as these which utilize a multiliteracies framework can also help preservice instructors address gaps in preservice teachers' understandings of how to engage critically with media texts.

Central in this endeavour is the pedagogy of multiliteracies (New London Group, 1996) with its four components which we consider as we reflect on the findings of this study. The first is meaningful practice in a learning community who can play, "multiple and different roles based on their backgrounds and experiences" (p.85.) Our preservice teachers indicate that they are initially somewhat intimidated, but not overwhelmed, with the amount of technology that they are expected to use. They find more spaces for expression with the technology and they find voice where previously their voices may not have been heard. With the digital literacy histories 
assignment, the social justice book talks, and the introduction to critical media literacy, we are satisfied that we are providing meaningful, authentic practices in the preservice program. Preservice teachers, as both learners and teachers can begin to connect their understandings of power, voice, and representation to the need for social and educational change.

With respect to overt instruction in a multiliteracies pedagogy, the research has been helpful in identifying where we as preservice educators can scaffold learning activities and interventions to allow the preservice teachers to build on their understandings from other preservice teachers' experiences. Based on the review of the critical media literacy lessons, for example, we are reconstructing the assignment to scaffold the steps. Thoman and Jolls (2005) see the inquiry process in critical media studies as "two sides of the same coin" (p. 188). They theorize that inquiry in media literacy education needs both the production skills and the deconstruction skills. We have realized that the critical media literacy lesson assignment presently focuses more on deconstruction than production; attention to this imbalance might improve the outcomes of the assignment.

The third component of a multiliteracies pedagogy, critical framing, has presented us with some challenges. First, we find that some preservice teachers are challenged to articulate critical concepts. For example, multiple preservice teachers indicate that they are unhappy about advertising and body image but most cannot articulate underlying assumptions associated with judging women by their appearance, or recognizing a relationship between a public unhappy with body size and the media sell of gym memberships and weight loss programs. In addition, we have found that some preservice teachers are not aware that representations of meaning, whether they are in texts or media, are sites of present complexity and struggle. They see some issues, such as gender discrimination and racism, as points of conflict in the past rather than the present.

In addition, some preservice teachers indicate that they are not sure that they should have a role in leading students to examine media and print critically. Our findings resonate with those of Kelly and Brandes (2001) who theorize that teachers' visions of democracy in Canada differ: some feel that the teacher's role is not to question; some want students to have multiple perspectives but see the playing field as level; but a third teacher perspective recognizes inequalities and sees a need for social action (Kelly \& Brandes, 2001). We concur that preservice instructors should lead preservice teachers to consider that they have a role to play in building a more democratic future.

Luke and Freebody (1997) have identified critical literacy as a set of literacy practices that help students become aware that text can present points of view while missing or silencing other points of view. Supporting preservice teacher discourse on these and similar understandings is a direction forward for us as teacher educators. Technology opens another window for addressing issues of power, voice and representation (Alvermann \& Hagood, 2000; Jewitt, 2008a; Kellner, 2000) as does media literacy (Floures-Koulish, 2006). As instructors, we need to find ways to frame the issues in ways that preservice teachers can understand, possibly through the introduction of pedagogical models of critical literacy (e.g., Ciardiello, 2004).

The final component of a multiliteracies pedagogy is transformed practice, by which we mean that preservice teachers will connect critical literacy understandings to the need for social and educational change. Technology's affordances allow us to employ new digital technologies and new learning strategies to transform our teaching and learning in positive directions for society and in ways that can empower both our preservice teachers and their future students 
(Labbo \& Reinking, 1999). Kellner (2000) argues also that new literacies should be considered for how they can empower people who have traditionally been excluded; in this way, education can be reconstructed to be more responsive in a multicultural society. While there were elements of transformed practice evident in the data, there was also room for growth in this outcome area.

While our study confirms that the preservice teachers are gaining experience and expertise with multiliteracies, we are aware that the rules and conventions of multiliteracies are continually evolving (Kellner, 2000) and we need to make a deliberate effort toward the continuous improvement and updating of the ELA course in order to keep up with changes in society and in technology affordances. At the same time, we need to encourage preservice teachers to be comfortable in both the print and digital worlds. Kellner (2000) considers that these new multimedia sites are the "new frontier of learning and literacy, the great challenge to education for the millennium" (p. 256). Again, the findings of the study and our understandings of the literature, confirm our earlier direction toward an emphasis on critical media literacy.

We began this study with a focus on the ELA program and its respective elements without a key consideration of the thematic elements that linked all of the components of our study. We have moved now to a place where we see new literacies, and transformed practice using technology, as central themes that will support and sustain our future reflective efforts. The recursive nature of the study is a rich source of data, contemplation, and discourse for us. Also, we hope that our story resonates with other preservice teacher educators employing new literacies and new technologies in their work with preservice teachers. From a sociolinguistic perspective, we are reminded by Gee (1996) and the New London Group (1996) that literacy is embedded in the social practices of a culture. As we continue to develop theories of new literacies, we recognize that "multiple, critical literacies populate the new literacies ... requiring new skills, strategies and insights to successfully exploit the rapidly changing information and media technologies continuously emerging in our world " (Leu, Kinzer, Coiro \& Cammack, 2004). It will be helpful to share approaches which encourage preservice teachers to successfully accomplish these goals: to bring to the surface their assumptions; to teach in new ways; to participate fully in a democratic society; and to consider themselves change agents for a better world.

\section{References}


Alvermann, D.E. and Hagood, M. C. (2000). Critical media literacy: Research, theory and practice in "new times." The Journal of Educational Research, 93(3), 193-205.

Bearne, E. (2003). Rethinking literacy: Communication, representation and text. Reading, 37(3), 98-103. doi:10.1046/j.0034-0472.2003.03703002.x

Berg, B. (2004). Qualitative research methods for the social sciences $\left(5^{\text {th }}\right.$ Ed.). Boston, MA: Pearson Education, Ltd.

Black, R. (2007). Digital design: English language learners and reader reviews in online fiction. In M. Knobel \& C. Lankshear (Eds.), A new literacies sampler. New York: Peter Lang.

Brandes, G. \& Kelly, D. (2004). Teaching for social justice: Teachers inquire into their practice. In M. Shamser, E. Decker, G. Brandes \& D. Kelly, D. (Eds.), Teaching for Social Justice (pp. 7-21). Vancouver: UBC \& BC Teachers Federation. Retrieved from http://bctf.ca/uploadedFiles/Public/ProD/TeacherResearch/TeachingForSocialJustice.pdf\#page=9/

Brookfield, S. (1995). Becoming a critically reflective teacher. San Francisco: Jossey-Bass.

Bruner, J. (1994). Acts of meaning: Four lectures on mind and culture. Cambridge, MA: Harvard University Press.

Burn, A. (2008). The case of rebellion: Researching multimodal texts. In J. Coiro, M. Knobel, C. Lankshear \& D. Leu (Eds.), Handbook of research on new literacies (pp. 151-178). NY: Lawrence Erlbaum Associates.

Christensen, L. (2004). Bringing students' lives into the classroom. In B. Bigelow, B. Harvey \& S. Karp (Eds.). Rethinking our classrooms, Volume 2: Teaching for equity and justice (pp. 6-10). Milwaukee, Wisconsin: Rethinking Schools.

Ciardiello, D. (2004). Democracy's young heroes: An instructional model of critical literacy practices. The Reading Teacher, 58(2), 138- 147.

Conklin, H. (2008). Modeling compassion in critical, justice-oriented teacher education. Harvard Educational Review, 78(4), 652-674.

Cope, B. \& Kalantzis, M. (2000). Multiliteracies: Literacy learning and the design of social futures. London: Routledge.

Cranton, P. \& King, K. (2003). Transformative learning as a professional development goal. New Directions for Adult and Continuing Education, 98, 31 -37.

Cummins, J., Brown, K., \& Sayers, D. (2007). Literacy, technology, and diversity:Teaching for success in changing times. Boston: Allyn \& Bacon. 
Gee, J.P. (1996). Social linguistics and literacies: Ideology in discourses. London: Taylor \& Francis.

Ferrarelli, M. (2007). Children's literature and gender. A cultural approach. In L.M. deSousa (Ed.), Critical literacy: Theories and practices. Volume 1:1, July 2007. Retrieved from http://www.criticalliteracyjournal.org/cljournalissue1volume1.pdf/

Floures-Koulish., S. (2006). Media literacy: An entrée for pre-service teachers into critical pedagogy. Teaching Education, 17(3), 239-249.

Hamanaka, S. (1994). All the colors of the earth. New York, NY: HarperCollins.

Hughes, J., \& Robertson, L. (2010). Transforming practice: Using digital video to engage students. Contemporary Issues in Technology and Teacher Education, 10 (1). Retrieved from http://www.citejournal.org/vol10/iss1/languagearts/article2.cfm

Hughes, J., \& Robertson, L. (2011). Teachers as moral compasses: Exploring critical literacy through digital social justice book talks. Language and Literacy. 13(2) Special Issue, 201, 24-37.

Hull, G.A.. \& Katz, M. (2006). Creating an agentive self: case studies of digital storytelling. Research in the Teaching of English, 41(1), 43-81.

Jewitt, C. (2008a). Multimodality and literacy in school classrooms. Review of research in education, 32, February, 2008, 241-267.

Jewitt, C. (2008b). Technology, literacy, learning: A multimodal approach. New York: Routledge.

Keegan, P. (2011). Transformative e-learning and teaching in mandatory tertiary education. Asian Social Science, 2(11), 66-74.

Kellner, D. (2000). New technologies/new literacies: reconstructing education for the new millennium. Teaching Education, 11(3), 245-265.

Kellner, D., \& Share, J. (2007). Critical media literacy, democracy, and the reconstruction of education. In D. Macedo and S. Steinberg (Eds.), Media literacy: A Reader, NY: Lang.

Kelly, D., \& Brandes, G. (2001). Shifting out of "neutral”: Beginning teachers' struggles with teaching for social justice. Canadian Journal of Education, 26(4), 437-454.

Kilodavis, C. (2010). My princess boy. Seattle, WA: KD Talent LLC.

King, K. (2002). Educational technology professional development as transformative learning opportunities. Computers \& Education, 39, 283-297. 
Kress, G. (2003). Literacy in the new media age. London: Routledge.

Kress, G., \& Van Leeuwen, T. (2001). Multimodal discourse: The modes and media of contemporary communication. New York: Oxford University Press.

Labbo, L., \& Reinking, D. (1999). Negotiating the multiple realities of technology in literacy research and instruction. Theory and Research into Practice, 34(4), 478-492.

Lankshear, C., \& Knobel, M. (2006). New literacies: Everyday practices and classroom learning. Buckingham, UK: Open University Press.

Leu, D. J., Jr., Kinzer, C.K., Coiro, J., \& Cammack, D.W. (2004). Toward a theory of new literacies emerging from the Internet and other information and communication technologies. In R.B. Ruddell, \& N. Unrau (Eds.), Theoretical models and processes of reading (5th ed., pp. 1570-1613). Newark, DE: International Reading Association. Available: http://www.readingonline.org/newliteracies/lit_index.asp?HREF=leu/

Lewison, M., Flint, A. S., \& Van Sluys, K. (2002). Taking on critical literacy: The journey of newcomers and novices. Language arts, 79(5), 382-392.

Luke, A., \& Freebody, P. (1997). Shaping the social practices of reading. In S. Muspratt, A. Luke, \& P. Freebody (Eds.), Constructing critical literacies: Teaching and learning textual practice (pp. 185-225). Cresskill, NJ: Hampton.

McIntosh, P. (1989). White privilege: Unpacking the invisible knapsack. Peace and Freedom, July/August, 1989.

McLaughlin, M., \& DeVoogd., G. (2004). Critical literacy: Enhancing students' comprehension of text. New York: Scholastic.

Mezirow, J. (2000). Transformative learning as discourse. Journal of Transformative Education, $1(1), 58-63$.

Moller, K. (2002). Providing support for dialogue in literature discussions about social justice. Language Arts, 79(6), 467-476.

New London Group. (1996). A pedagogy of multiliteracies: Designing social futures. Harvard Educational Review, 66(1), 60-92.

Pajares, M.F. (1992). Teachers' beliefs and educational research: Cleaning up a messy construct. Review of Educational Research 62(3), 307-332.

Robertson, L., Hughes, J., \& Smith, S. (2012). Thanks for the assignment: Digital literacy in teacher pre-service. Language and Literacy, 14(1), 1-13. 
Robertson, L., \& Hughes, J. (2011).Investigating preservice teachers' grasp of critical media literacy. Language and Literacy. 13(2) Special Issue, 201, 37-53.

Stake, R. (2000). Case Studies. In N. Denzin \& Y. Lincoln (Eds.), Handbook of qualitative research ( $2^{\text {nd }} E d$.). (pp. 435-454). Thousand Oaks, CA: Sage Publication.

Thoman, E., and Jolls, T. (2005). Media literacy education: Lessons from the center for media literacy. Yearbook of the National Society for the Study of Education, 104(1), 180-205. doi: 10.1111/j.1744-7984.2005.00011.x 